\title{
Effect of using sweet potato powder on diabetic rats ${ }^{1}$
}

\author{
Zeinab A.E. Hawash*, Farrag**, A. A. and Hanan S. E. Eldamaty*** \\ * Demonstrator of Nutrition and Food Sciences, Nutrition and Food Sciences \\ Dept., Faculty of Home Economics, Al-Azhar University \\ **Professor of Food Science, Nutrition and Food Science Dept. and Vice Dean \\ for Education and Student Affairs previously. Faculty of Home Economics, \\ Helwan University \\ *** Lecturer of Nutrition and Food Science, Nutrition and Food Sciences Dept., \\ Faculty of Home Economics, Al-Azhar University
}

\begin{abstract}
The main aim of this research was to study the influence of sweet potato powder on diabetic rats. A total of 24 adult male albino rats of "Sprague Dawley" strain $(150 \pm 5 \mathrm{~g})$ were used and randomly divided into 4 equal groups including negative control group, positive control group, while the other two groups were treated with $10 \%$ raw potato and $30 \%$ cooked potato depending on sensory evaluation of biscuits supplemented with raw and cooked sweet potato powder. The experiment lasted for 28 days. Measurements included determining glucose, liver functions, kidney functions and lipid profile in serum and pancreas histopathology. The results indicated that induced alloxan resulted in significant increases in glucose in urine and serum, in addition to a significant increase in liver and kidney functions, lipid profile expect HDL-C were decreased compared with a negative control group and abnormal histopathological changes were noticed in pancreas dysfunction resulted from abnormal histopathology was observed. Like raw and cooked sweet potato induced anti-diabetic effects and decreased glucose in blood serum. Moreover, they alleviated alloxan-induced abnormalities in body weight, liver and kidney functions. Accordingly, this study recommends diabetic patients to regularly consume sweet potato and its leaves with a suitable dose since they can induce an improvement in increase blood sugar.
\end{abstract}

Keywords: Diabetes mellitus, alloxan, sweet potato, insulin, lipid profile.

\footnotetext{
1 This research was extracted from Thesis M.Sc. under title Effect of using sweet potato powder and leaves on diabetic rats, to Demonstrator: Zeinab Abd Elsalam Ragab Hawash
} 


\section{INTRODUCTION}

Blood sugar is the problem of chronic high diabetics in blood and it has been subdivided into type 1 diabetes (the autoimmune destruction of $\beta$ cells) and also, type 2 diabetes (with insulin resistance and features of the relating to syndrome) (Tuomi et al., 2014).

Diabetes mellitus (DM) is a significant public health problem, considered one of the highest challenges in our century owing to the number of people suffering from DM has massively increased in the last 20 years (Sandu et al., 2016). $\mathrm{DM}$ is a metabolic disorder that is characterized by chronic high blood glucose level that leads to complications in the eyes, kidneys, heart, vessels and nerves (Park and Jang, 2016).

Blood sugar is a happen either when the pancreas does not produce sufficient insulin or when the body cannot use the insulin it produces. Elevate diabetes is a result of uncontrolled blood sugar and leads to dangerous injure to many of the body's systems (WHO, 2018).

Patients with blood sugar type 2 constitute about $90 \%-95 \%$ in worldwide. People with hyperglycemia are at the greatest danger of macrovascular and microvascular complications (Hegazi et al., 2015).

This chronic complex disease requiring permanent medical care involving risk-reduction strategies is beyond blood sugar control (ADA, 2017). More therapy drugs are commercially available for utilizing in the administration of blood sugar, their side influences and expensive confirm the necessity to natural products as a replacement therapy (Hossen et al., 2017). For example, metformin is a biguanide which can cause vitamin B12 and folic acid deficiency (Fogelman et al., 2017).

Strugala et al (2019) estimated that influence of purple potato (PP) on diabetes and its antioxidant activities after two-week management to streptozotocin (STZ)-induced diabetic rats. The findings observed that the PP showed antioxidative impact, inhibition malondialdehyde levels, and restored antioxidant enzyme activities in diabetic rats. In addition, the inhibition of oxidative modified proteins, progress glycation end-product, and advanced oxidation protein product formation in the rats' blood plasma utilizing a purple potato.

Sweet potato is abundant in dietary fiber, minerals, vitamins and compound of substance with biological effect such as B carotene, phenolic acid and anthocyanin that give sweet potato its unique flesh colors (cream, yellow, orange and purple) (Teow, 2007). The anthocyanin that found in sweet potato could regulate the blood glucose level by inhibit the alpha-glucosidase (Ghosh and Konishi, 2007) and could also increase the phosphorylation of insulin receptor (Nizamutdinova et al., 2009). The antioxidant agents of this potatoes 
increased antioxidant enzymes, which is superoxide dismutase (SOD) (Jawi and Budiasa, 2011).

Sweet potato had contained carbohydrates, proteins, vitamins and natural antioxidants in various ratios depending on the variety. It has been found high amounts from phenolic as caffeic acid and flavonoids compounds like quercetin (Wang et al., 2016). Vitamins and natural antioxidants are some of the bioactive compounds which are particularly abundant in the purple-potato varieties (He et al., 2015 and Alam et al., 2016). The pharmacological mechanism of this hypoglycemic effect is still studied. One of the proposed mechanisms is a protection of pancreatic $\beta$ - cells by the antioxidant agents of this sweet potato (Jawi et al., 2016).

This research was achieved to investigate influence treatment of raw and cooked sweet potato powder on diabetic rats. The influences of sweet potato powder on feed intake, body weight gain, and liver and kidney functions were also studied.

\section{Materials:}

\section{MATERIALS AND METHODS}

The yellow sweet potato (Ipomoea batatas L) was obtained from the local market, Tanta City, Gharbia Governorate, Egypt.

Casein was obtained from El -Sharqiya Co., while vitamin and salt mixture were obtained from Adwiya Co., Kafr El- Zayat, Egypt. Fats, cellulose powder, sugar, corn oil and corn starch was purchased from local market, Tanta City, Gharbia Governorate, Egypt.

Wheat flour $72 \%$ extraction, sugar, salt, vegetable oil, egg, vanillin and ammonium bicarbonate were purchased from the local market Tanta City, Gharbia Governorate, Egypt

Alloxan monohydrate was purchased from El-Gomhorya Company for Chemicals and Drugs, Tanta City, Gharbia Governorate, Egypt.

A total of twenty four (24) adult male albino rats of "Sprague Dawley" strain $(150 \pm 10 \mathrm{~g})$ were obtained from the Animal Colony, Helwan Farm, Vaccine and Immunity Organization, Ministry of Health, Cairo Governorate, Egypt.

Methods:

\section{Preparation of plant materials:}

The yellow sweet potato was being washed thoroughly with clean water, sliced cut into small pieces. The sliced portions were being soaked in warm water to prevent subsequent browning, another portion of sweet potato was being cooked in boiling water were sundried for about 10 days. The dried samples of slices were being blended into powder separately then it was being transferred into a plastic package with cover and labeled accordingly.

Chemical constituents of raw and cooked sweet potato: 
Moisture, protein, total fat, ash and crude fiber were determined in raw materials (raw sweet and cooked sweet potato) and also, some minerals as calcium, potassium and magnesium were determined according to $\mathrm{AOAC}$ (2012).

\section{Preparation of biscuits sample:}

Samples were prepared with biscuits supplemented with raw sweet and cooked potato powder was prepared at 3 levels $(10,20$ and 30\%). The best results were chosen based on the sensory evaluation by trained panelists. Biscuits sample supplemented with $10 \%$ raw sweet potato and $30 \%$ cooked sweet potato were used in a biological experimental.

\section{Preparation of biscuits:}

Marie type biscuits were prepared according to a commercial formula and baking in Bisco Misr Company. The base recipe is given in table (1) wheat flour was replaced with raw sweet potato powder and cooked sweet potato powder) at levels 10,20 and $30 \%$. After baking at $220^{\circ} \mathrm{C}$ for 12 minutes and cooling for 30 minutes, the biscuits were packed into polythene bags for chemical and sensory evaluation.

\section{Organoleptic Evaluation}

The organoleptic evaluation of biscuits was carried out using a panel test according to Sudha et al.(2007). The trained panelists of Nutrition and Food Sciences Dept., Faculty of Home Economics, Al-Azhar University were asked to evaluate the biscuits for color, texture, acceptability, odor, hardness and taste The results were subjected to the statistical analysis according to the least significant differences test at $\mathrm{p}<0.05$ level was used to verify the differences among treatments.

Table (1): Biscuits supplemented with raw and cooked sweet potato powder at levels 10 and $30 \%$.

\begin{tabular}{|c|c|c|c|}
\hline Ingredients & Control & $\begin{array}{c}\text { Raw sweet } \\
\text { potato10\% }\end{array}$ & $\begin{array}{c}\text { Cooked sweet } \\
\text { potato30\% }\end{array}$ \\
\hline $\begin{array}{c}\text { Wheat flour 72\% } \\
\text { extraction }\end{array}$ & $100 \mathrm{~g}$ & $90 \mathrm{~g}$ & $\mathbf{7 0} \mathrm{g}$ \\
\hline Egg & $20 \mathrm{~g}$ & $\mathbf{2 0 g}$ & $\mathbf{2 0 g}$ \\
\hline Sucrose & $30 \mathrm{~g}$ & $\mathbf{3 0 g}$ & $\mathbf{3 0 g}$ \\
\hline Vegetable oil & $\mathbf{3 5 g}$ & $\mathbf{3 5 g}$ & $\mathbf{3 5 g}$ \\
\hline Vanillin & $\mathbf{0 . 4 g}$ & $\mathbf{0 . 4 g}$ & $\mathbf{0 . 4 g}$ \\
\hline Salt & $\mathbf{0 . 1 5 g}$ & $\mathbf{0 . 1 5 g}$ & $\mathbf{1 5 g}$ \\
\hline $\begin{array}{c}\text { Ammonium } \\
\text { bicarbonate }\end{array}$ & $1.2 \mathrm{~g}$ & $1.2 \mathrm{~g}$ & $\mathbf{1 0 m l}$ \\
\hline Water & $10-15 \mathrm{ml}$ & $25 \mathrm{ml}$ & \\
\hline
\end{tabular}




\section{Biological experimental}

\section{A) Animals}

Male Albino rats $(n=24)$ of Sprague Dewey Strain weighting $(150 \pm 10$ g) were kept in single wire cages with wire bottoms under hygienic conditions. The diet was fed in Table (2) according to Pell et al. (1992). Also, water was provided to the rats by glass tube projection through the wire cages. Food and water were provided ad-libitum and checked daily.

Table (2): Percentage composition of the experimental diet (g/100 g).

\begin{tabular}{|c|c|c|c|c|}
\hline Diet & Control (-) & Control (+) & $\begin{array}{c}\text { RSPFP } \\
\text { (Row) }\end{array}$ & $\begin{array}{c}\text { CSPFP } \\
\text { (cooked) }\end{array}$ \\
\hline Casein & $\mathbf{1 0}$ & $\mathbf{1 0}$ & $\mathbf{1 0}$ & $\mathbf{1 0}$ \\
\hline $\begin{array}{c}\text { Vitamin } \\
\text { mixture }\end{array}$ & $\mathbf{1}$ & $\mathbf{1}$ & 1 \\
\hline Salt mixture & $\mathbf{4}$ & $\mathbf{4}$ & $\mathbf{4}$ & $\mathbf{4}$ \\
\hline Cellulose & $\mathbf{5}$ & $\mathbf{5}$ & $\mathbf{5}$ & $\mathbf{5}$ \\
\hline Corn oil & $\mathbf{1 0}$ & $\mathbf{1 0}$ & $\mathbf{1 0}$ & $\mathbf{1 0}$ \\
\hline Starch & $\mathbf{7 0}$ & $\mathbf{7 0}$ & $\mathbf{6 0}$ & $\mathbf{4 0}$ \\
\hline Powdered & & & 10 & $\mathbf{3 0}$ \\
\hline
\end{tabular}

The rats were randomly divided into two main groups, the first main group-containing (6) rats as a negative control group fed on basal diet. The second group (18) rats were injected by $120 \mathrm{mg} / \mathrm{kg}$ body weight of alloxan monohydrate in normal saline water in a volume of about $3 \mathrm{~mL}$. After 72 hours of alloxan injection, we were done urine examination each to rat, the diabetic rats (glucose level $>250 \mathrm{mg} / \mathrm{dL}$ ) according to Yaday et al. (2008). The second diabetics' rats group was re-divided to the positive group fed on basal diet. In addition, two diabetics' rats' groups were fed on diet containing 10 and $30 \%$ raw and cooked sweet potato.

The body weight rats were recorded every week and at the end of the experimental period, rats were fasted overnight and anaesthetized using diethyl ether and blood samples were taken and centrifuged at 5000 r p.m for 15 minutes to separate serum, and then kept in plastic vials at $-20{ }^{\circ} \mathrm{C}$ until analysis.

Blood glucose was determined according to the method described by Trinder, (1969). Liver function enzymes as AST and ALT were determined in the serum according to the method described by Murray (1984), whereas, alkaline phosphates (ALP) was determined according to Wenger and Kaplan, (1984). Kidney functions serum urea and creatinine were determined according to Kaplan, (1984) and Murray (1984), 
Total Cholesterol was determined in the serum according to the method described by Allain et al.(1974) Serum HDL -C, LDL-C and VLDL -Cwere determined according to Friedwald $\boldsymbol{e t}$ al. (1972). Triglycerides were determined in the serum according to the method described by (Trinder and Ann, 1969).

\section{Histological analysis:}

Specimen of the pancreas was taken immediately after sacrificing rats and immersed in $10 \%$ neutral buffered formalin, the fixed specimens were then trimmed and dehydrated in ascending grades of alcohol, cleared in xylene, embedded in paraffin, sectioned (4-6 micro thickness), stained with hematoxylen -eosin and examined microscopically (Carleton, 1979).

\section{Statistical analysis:}

Statistical analysis was carried out using the programme of Statistical Package for the Social Sciences (SPSS), PC statistical software (Version 11; Untitled - SPSS-Data Editor). The results were expressed as mean \pm standard error (mean \pm S.E.). Data were analyzed using one way classification, analysis of variance (ANOVA). The difference between means were tested for significance using least significant difference (Duncan, 1955) test at $\mathrm{P}<0.05$. Independent $\mathrm{T}$ test was also used to determine the statistical difference between two means.

\section{RESULTS AND DISCUSSION}

\section{Chemical analysis of raw and cooked sweet potato:}

Results in Table (3) showed that chemical analysis of the raw sweet potato and cooked sweet potato. Cooked sweet potato has the highest value in moisture $(8.37 \pm 0.42)$ and total carbohydrates $(72.65 \pm 0.38)$ followed by raw sweet potato $(7.06 \pm 0.04$ and $69.41 \pm 0.62)$, respectively. While the highest value of protein and fiber were recorded for raw sweet potato $(5.19 \pm 0.17$ and $13.22 \pm 0.85)$ then cooked sweet potato $(4.27 \pm 0.32$ and10.15 \pm 0.86$)$. Sweet potato cooked and raw were recorded the highest value in ash and potassium $(4.43 \pm 0.50,1.58 \pm 0.26)$ and $(2.97 \pm 0.19,0.83 \pm 0.07)$, respectively. In addition the highest value in calcium and $\mathrm{Mg}$ were recorded for cooked sweet potato $(0.14 \pm 0.01,0.15 \pm 0.03)$ followed by raw sweet potato $(0.09 \pm 0.01$ and $0.13 \pm 0.03)$.

The result of proximate analysis of orange sweet potato flour indicated that it contained $68.92 \%$ carbohydrate, $5.32 \%$ crude protein, ether extract $2.10 \%$ ash and $0.80 \%$ crude fiber (Samiha, 2015).

Sweet potato (SP) flour showed that the range of values for the composition of flour had contained high amounts the chemical constituents like moisture content $(8.06-12.86 \%)$, protein $(0.55-5.87 \%)$, fat $(0.04-1.45 \%)$, fiber $(0.08-5.54 \%)$, ash $(0.15-2.09 \%)$ and carbohydrate $(74.55-90.92 \%)$, 
respectively. (Ganiyat et al. 2016). Also, Rodrigues et al., (2016) showed the chemical composition of orange sweet potato flour that contains moisture, ash, protein, fats, starch, fiber, total carbohydrates. The mean values were $10.97 \pm$ $0.95,2.11 \pm 0.12,4.80 \pm 0.24,0.39 \pm 0.03,33.66 \pm 3.76,2.57 \pm 0.14$ and $90.13 \pm 8.35$, respectively.

Table (3): Chemical analysis of raw and cooked sweet potato g/100g

\begin{tabular}{|c|c|c|}
\hline Components\% & Raw Sweet Potato & Cooked Sweet Potato \\
\hline Moisture\% & $7.06 \pm 0.04^{b}$ & $8.37 \pm 0.42^{\mathrm{a}}$ \\
\hline Total Carbohydrates\% & $69.41 \pm 0.62^{b}$ & $72.65 \pm 0.38^{\mathrm{a}}$ \\
\hline Protein \% & $5.19 \pm 0.17^{b}$ & $4.27 \pm 0.32^{c}$ \\
\hline Fat $\%$ & $1.58 \pm 0.35^{\mathrm{a}}$ & $0.00 \pm 0.00^{c}$ \\
\hline Fiber $\%$ & $13.22 \pm 0.85^{b}$ & $10.15 \pm 0.86^{c}$ \\
\hline Ash\% & $2.97 \pm 0.19^{c}$ & $4.43 \pm 0.50^{b}$ \\
\hline Calcium mg/100g & $0.09 \pm 0.01^{b}$ & $0.14 \pm 0.01^{b}$ \\
\hline Potassium mg/100g & $0.83 \pm 0.07^{\mathrm{c}}$ & $1.58 \pm 0.26^{b}$ \\
\hline Magnesium & $0.13 \pm 0.03^{b}$ & $0.15 \pm 0.033^{b}$ \\
\hline
\end{tabular}

Means in the same column with various letters are significantly varied at $(p<0.05)$.

\section{Sensory evaluation of biscuits:}

Sensory evaluation of biscuits supplemented with raw and cooked sweet potato at levels $10,20,30 \%$, respectively, compared with control biscuit made from wheat flour $72 \%$ extraction and the finding are tabulated in Table (5). From the results it cleared that the best results of the sensory evaluation were indicated the use of both $10 \%$ raw and $30 \%$ cooked sweet potato powder and support for rat fed with these proportions.

Sensory evaluations revealed that biscuits produced from ratio wheat flour $72 \%$ extraction as control were not significantly influenced $(p \leq 0.05)$ in taste than biscuits were prepared from sweet potato at level 10 and $30 \%$. In this respect (Onabanjo and Ighere, 2014) reported that the color and overall acceptability between biscuits produced at levels $10,30,40$ and 50\% potato flour had no significant variation than control biscuit during the evaluation. Moreover, most of the panelist reported that biscuits made from ratio 10and $30 \%$ were more acceptable 
Table (4): Sensory evaluation of biscuits supplemented with raw and cooked sweet potato powder compared to control

\begin{tabular}{|c|c|c|c|c|c|c|}
\hline Groups & Color & Taste & Oder & Texture & Acceptability & Hardness \\
\hline Control & $8.78 \pm 1.42^{\mathrm{a}}$ & $8.33 \pm 1.47^{\mathrm{a}}$ & $4.26 \pm 0.82^{\mathrm{a}}$ & $4.05 \pm 0.65^{a}$ & $8.47 \pm 1.15^{\mathrm{a}}$ & $8.71 \pm 1.29^{a}$ \\
\hline $\begin{array}{r}\text { Raw } \\
\text { potato } \\
10 \%\end{array}$ & $8.10 \pm 1.27^{\text {ab }}$ & $8.05 \pm 1.30^{a b}$ & $3.87 \pm 0.80^{a b}$ & $4.08 \pm 0.62^{\mathrm{a}}$ & $8.28 \pm 1.28^{a b}$ & $8.51 \pm 1.70^{a}$ \\
\hline $\begin{array}{r}\text { Raw } \\
\text { potato } \\
20 \%\end{array}$ & $7.82 \pm 1.68^{b}$ & $7.38 \pm 2.12^{b}$ & $3.79 \pm 1.10^{b}$ & $4.03 \pm 0.87^{\mathrm{a}}$ & $7.72 \pm 2.49^{\mathrm{ab}}$ & $8.97 \pm 0.99^{a}$ \\
\hline $\begin{array}{r}\text { Raw } \\
\text { potato } \\
30 \%\end{array}$ & $7.59 \pm 1.77^{b}$ & $7.44 \pm 1.92^{b}$ & $3.64 \pm 0.99^{b}$ & $3.85 \pm 0.84^{\mathrm{a}}$ & $7.49 \pm 1.90^{b}$ & $9.1 \pm 1.1 .19^{a}$ \\
\hline $\begin{array}{r}\text { Cooked } \\
\text { potato } \\
10 \%\end{array}$ & $7.69 \pm 1.96^{b}$ & $7.56 \pm 1.57^{\mathrm{a}}$ & $3.72 \pm 0.89^{b}$ & $3.72 \pm 1.00^{\mathrm{a}}$ & $7.38 \pm 1.62^{b}$ & $7.56 \pm 1.93^{b}$ \\
\hline $\begin{array}{r}\text { Cooked } \\
\text { potato } \\
20 \%\end{array}$ & $8.05 \pm 1.50^{\mathrm{ab}}$ & $7.56 \pm 1.57^{\mathrm{a}}$ & $3.90 \pm 0.85^{\mathrm{ab}}$ & $3.74 \pm 1.02^{\mathrm{a}}$ & $7.49 \pm 1.70^{b}$ & $7.56 \pm 1.87^{b}$ \\
\hline $\begin{array}{r}\text { Cooked } \\
\text { potato } \\
30 \% \\
\end{array}$ & $7.85 \pm 1.55^{\mathrm{a}}$ & $8.44 \pm 1.25^{\mathrm{a}}$ & $4.10 \pm 0.94^{\mathrm{ab}}$ & $3.82 \pm 1.00^{\mathrm{a}}$ & $7.69 \pm 1.70^{b}$ & $7.90 \pm 1.77^{b}$ \\
\hline
\end{tabular}

Means in the same column with various letters are significantly varied at $(\mathrm{p}<0.05)$.

\section{Biological experimental}

Influence of sweet potato powder on food intake (FI), body weight gain (BWG) and feed efficiency ratio (FER) on diabetic rats

From the result in Table (4) showed that negative control recorded a significant increase in food intake and gain body weight $(14.60 \pm 1.00$ and $53.14 \pm 9.56 \mathrm{~g})$ as compared to a positive control $(11.35 \pm 1.68$ and $34.95 \pm 7.49 \mathrm{~g})$. No significant difference in food intake among the groups which were treated with $10 \%$ raw potato $(13.48 \pm 2.17 \mathrm{~g})$ and $30 \%$ cooked potato $(15.12 \pm 1.57 \mathrm{~g})$. Meanwhile, a significant difference in BWG between the groups which treated with $10 \%$ raw potato $(45.28 \pm 8.45 \mathrm{~g}), 30 \%$ cooked potatoes $(42.33 \pm 9.91 \mathrm{~g})$ as compared to positive group $(34.95 \pm 7.49 \mathrm{~g})$. In addition, the results from feed efficiency ratio was parallel the results from food intake and gain bodyweight.

The decreases in body weight may be caused by the elevate amount of feed consumed for the presence of protease inhibitor which had been found to lowering proteolytic enzyme activity, thereby reducing nutrient absorption (Eusebio et al., 2004).

Akram et al. (2018) demonstrated the body weight of diabetic rats after two week treatment with water extract of white skin sweet potato (WSSP) peel and found decrease in body weight was caused that the sweet potatoes are rich in dietary fibers and low glycemic index with decreasing digestion and delays gastric emptying time. 
Table (5): The effect of sweet potato powder on feed intake, body weight gain and feed efficiency ratio in diabetic rats

\begin{tabular}{|c|c|c|c|}
\hline Groups & FI (g)/d & BWG (g) & FER \\
\hline Negative control & $14.60 \pm 1.00^{\mathrm{a}}$ & $53.14 \pm 9.56^{a}$ & $0.13 \pm 0.01^{\mathrm{a}}$ \\
\hline Positive control & $11.35 \pm 1.68^{b}$ & $34.95 \pm 7.49^{\mathrm{c}}$ & $0.11 \pm 0.03^{\mathrm{ab}}$ \\
\hline $10 \%$ raw potato & $13.48 \pm 2.17^{\mathrm{a}}$ & $45.28 \pm 8.45^{\mathrm{ab}}$ & $0.12 \pm 0.02^{\mathrm{ab}}$ \\
\hline $30 \%$ cooked potato & $15.12 \pm 1.57^{\mathrm{a}}$ & $42.33 \pm 9.91^{b}$ & $0.10 \pm 0.02^{b}$ \\
\hline
\end{tabular}

Means in the same column with various letters are significantly varied at $(\mathrm{p}<0.05)$.

\section{Influence of sweet potato powder on lipid profile and glucose on diabetic rats}

Lipid profile as triglycerides, total cholesterol, cholesterol fractions and glucose in serum were determined in diabetics' rats groups and the results are reported in Table (6).

Results demonstrated that, positive control markedly recorded high significant increase in serum glucose $(146.33 \pm 13.47 \mathrm{mg} / \mathrm{dl})$ as compared to negative control group $87.00 \pm 3.58$ ). Percentage of increase in serum glucose was $68.2 \%$.The nearest results for normal group were noticed in group treated with $10 \%$ raw potato $(97.83 \pm 11.3647 \mathrm{mg} / \mathrm{dl})$ followed by treated with $30 \%$ cooked potato $(126.00 \pm 15.7647 \mathrm{mg} / \mathrm{dl})$. These results are confirmed with Srijita (2015) suggested that sweet potatoes are a good food choice for diabetics; it could be high in fiber and lowering blood sugar. Therefore can assistance diabetics control their blood sugar.

Shaohualiu and Yunong (2016) observed that the sweet potato residue cellulose can be lowering the intestinal absorption of glucose and prevent postprandial hyperglycemia and inhibition the propagation of glucose and lipids; by lowering intestinal absorption of glucose and lipid, which is the synergistic influence of decreasing blood glucose.

Results from the same table observed that the positive control group recorded significant increase in total cholesterol $(124.12 \pm 25.8047 \mathrm{mg} / \mathrm{dl})$ as compared to negative control group $(83.49 \pm 4.9447 \mathrm{mg} / \mathrm{dl})$. The best results were recorded for groups which treated with $10 \%$ raw potato $(101.17 \pm 4.4547 \mathrm{mg} / \mathrm{dl})$ followed by $30 \%$ cooked potato $(116.50 \pm 5.8647 \mathrm{mg} / \mathrm{dl})$. These results are agreement with Omodariniro and Omodamiro (2018) who found that the sweet potato is a good anti-lipidemic plant and in addition serve as the best means of diabetes administration. Furthermore, total cholesterol in diabetic rats elevated than control and metformin-treated rats. This could be caused an increase in mobilization of free fatty acids from peripheral fat deposited. Management of aqueous sweet potato extract decreased the serum total cholesterol, TG and LDL concentrations while it significantly elevated the concentration of HDL (Rafiu and Luka, 2018). 
It was cleared that positive control group recorded significant decrease in HDL $(37.40 \pm 1.62 \mathrm{mg} / \mathrm{dl})$ as compared to negative control group $(49.17 \pm 5.7847 \mathrm{mg} / \mathrm{dl})$. It was showed that positive control group recorded significant increase in LDL $(63.25 \pm 9.3747 \mathrm{mg} / \mathrm{dl})$ as compared to negative control (17.47 \pm 8.74$)$. The best results were recorded for groups which treated with $10 \%$ raw potato $(39.67 \pm 5.41)$.Trindad et al., (2013) proved that sweet potato and cassava are good sources of dietary fiber and resistant starch. Sweet potato and cassava increased HDL-C and lowering LDL-C in humans with moderately raised serum glucose and cholesterol levels. Possible intake of sweet potato and cassava could be favorable in the protection for the danger of cardiovascular diseases in addition to obesity and type 2 diabetes mellitus.

It was found that positive control group recorded significant increase in T.G and VLDL $(117.40 \pm 12.8$ and $23.47 \pm 2.4447 \mathrm{mg} / \mathrm{dl})$ as compared to negative group $(84.85 \pm 5.28,16.85 \pm 1.2247 \mathrm{mg} / \mathrm{dl}$, respectively). While there were no significant difference in T.G and VLDL among all treated and negative control group. Group that treated with $10 \%$ raw sweet potato recorded significant decrease in T.G $(87.50 \pm 5.4747 \mathrm{mg} / \mathrm{dl})$ and VLDL $(17.50 \pm 1.0947 \mathrm{mg} / \mathrm{dl})$.

Table (6): Effect of sweet potato powder on lipid profile and glucose in serum of diabetic rats

\begin{tabular}{|c|c|c|c|c|c|c|}
\hline Groups & $\begin{array}{c}\text { T.C } \\
\text { (mg/dL) }\end{array}$ & $\begin{array}{c}\text { T.G } \\
\text { (mg/dL) }\end{array}$ & $\begin{array}{c}\text { HDL } \\
\text { (mg/dL) }\end{array}$ & $\begin{array}{c}\mathrm{LDL} \\
(\mathrm{mg} / \mathrm{dL})\end{array}$ & $\begin{array}{c}\text { VLDL } \\
\text { (mg/dL) }\end{array}$ & $\begin{array}{l}\text { Glucose } \\
\text { (mg/dL) }\end{array}$ \\
\hline $\begin{array}{c}\text { Negative } \\
\text { control }\end{array}$ & $\begin{array}{c}83.49 \\
\pm 4.94^{\mathrm{c}}\end{array}$ & $\begin{array}{c}\mathbf{8 4 . 8 5} \\
\pm 5.28 \\
\text { b }\end{array}$ & $\begin{array}{c}49.17 \\
\pm 5.78^{\mathrm{a}}\end{array}$ & $\begin{array}{c}17.47 \\
\pm 8.74\end{array}$ & $\begin{array}{c}16.85 \\
\pm 1.22^{b}\end{array}$ & $\begin{array}{c}\mathbf{8 7 . 0 0} \\
\pm 3.58 \\
\end{array}$ \\
\hline $\begin{array}{l}\text { Positive } \\
\text { control }\end{array}$ & $\begin{array}{r}124.12 \\
\pm 25.80^{a} \\
\end{array}$ & $\begin{array}{r}117.40 \\
\pm 12.8^{\mathrm{a}}\end{array}$ & $\begin{array}{r}37.40 \\
\pm 1.62^{c}\end{array}$ & $\begin{array}{r}63.25 \\
\pm 9.37^{\text {a }} \\
\end{array}$ & $\begin{array}{r}23.47 \\
\pm 2.44^{\text {a }}\end{array}$ & $\begin{array}{r}146.33 \\
\pm 13.47^{\mathrm{a}} \\
\end{array}$ \\
\hline $\begin{array}{c}10 \% \\
\text { raw } \\
\text { potato }\end{array}$ & $\begin{array}{l}101.17 \\
\pm 4.45^{\text {bc }}\end{array}$ & $\begin{array}{r}\mathbf{8 7 . 5 0} \\
\pm \mathbf{5 . 4 7 ^ { b }}\end{array}$ & $\begin{array}{r}44.00 \\
\pm 2.53^{b}\end{array}$ & $\begin{array}{l}39.67 \\
\pm 5.41^{c}\end{array}$ & $\begin{array}{c}17.50 \\
\pm 1.09^{b}\end{array}$ & $\begin{aligned} & 97.83 \\
\pm 11.36 & \end{aligned}$ \\
\hline $\begin{array}{l}30 \% \\
\text { cooked } \\
\text { potato }\end{array}$ & $\begin{array}{l}116.50 \\
\pm 5.86^{b}\end{array}$ & $\begin{array}{r}92.67 \\
\pm 8.04^{b}\end{array}$ & $\begin{array}{r}42.33 \\
\pm 2.42^{b}\end{array}$ & $\begin{array}{c}\mathbf{5 4 . 8 8} \\
\pm 4.96\end{array}$ & $\begin{array}{c}18.28 \\
\pm 3.23^{b}\end{array}$ & $\begin{array}{r}126.00 \\
\pm 15.76^{b}\end{array}$ \\
\hline
\end{tabular}

Means in the same column with various letters are significantly varied at $(\mathrm{p}<0.05)$.

\section{Influence of sweet potato powder on liver functions in diabetic rats}

Result in Table (7) illustrated that the positive control group recorded a significant increase in AST and ALT (75.55 17.87 and 42.93 $\pm 7.44 \mathrm{U} / \mathrm{L})$ as compared to the negative control group $(42.60 \pm 4.50$ and $25.40 \pm 4.50 \mathrm{U} / \mathrm{L})$ While there were no significant differences in AST and ALT between groups treated with 10 and $30 \%$ raw and cooked potatoes were gradually decreased.

AST and ALT activities act as an indicator of liver function, thus the reconquest of these enzymes after the management of Ipomoea batatas, point 
out that the normal functioning of the liver and the bile duct was restored (Udayakumar et al., 2009).

In the same table, it was noticed that the positive control group recorded a significant increase in ALP $(3.58 \pm 0.53 \mathrm{U} / \mathrm{L})$ as compared to negative control group $(2.58 \pm 0.26 \mathrm{U} / \mathrm{L})$. The rats' groups were treated with 10 and $30 \%$ raw and cooked potatoes and the results were decreased to $3.20 \pm 0.33$ and $3.25 \pm 0.60 \mathrm{U} / \mathrm{L}$, respectively, compared to control positive. The decreasing in ALP activity following Ipomoea batatas treatment found its stability of biliary function versus the risk due to by alloxan (Lathaet al., 2013).

Table (7): Effect of sweet potato powder on some liver functions in serum of diabetic rats

\begin{tabular}{|c|c|c|c|}
\hline Groups & AST (U/L) & $\operatorname{ALT}(\mathbf{U} / \mathbf{L})$ & $\operatorname{ALP}(\mathbf{U} / \mathbf{L})$ \\
\hline Negative control & $42.60 \pm 4.50^{c}$ & $25.40 \pm 4.50^{b}$ & $2.58 \pm 0.26^{b}$ \\
\hline Positive control & $75.55 \pm 17.87^{a}$ & $42.93 \pm 7.44^{\mathrm{a}}$ & $3.58 \pm 0.53^{\mathrm{a}}$ \\
\hline $10 \%$ raw potato & $70.00 \pm 10.73^{a}$ & $32.60 \pm 6.83^{b}$ & $3.20 \pm 0.33^{\mathrm{a}}$ \\
\hline $\begin{array}{c}30 \% \text { cooked } \\
\text { potato }\end{array}$ & $65.83 \pm 5.78^{\mathrm{ab}}$ & $26.75 \pm 3.87^{b}$ & $3.25 \pm 0.60^{\mathrm{a}}$ \\
\hline
\end{tabular}

Means in the same column with various letters are significantly varied at $(\mathrm{p}<0.05)$.

\section{Effect of sweet potato powder on kidney functions in serum of diabetic rats}

In Table (8) observed that there were no significant difference in urea among negative control group, positive control group, group treated with $10 \%$ raw potato. The values were $(42.40 \pm 2.42,46.83 \pm 5.34$ and $41.60 \pm 5.71$ $\mathrm{mg} / \mathrm{dL}$ respectively) and slightly significant decreased was recorded in group treated with $30 \%$ cooked potato was $38.83 \pm 5.56 \mathrm{mg} / \mathrm{dL}$. In the same table the positive control group recorded significant increase in creatinine $(0.92 \pm 0.10$ $\mathrm{mg} / \mathrm{dL})$ as compared to negative control $(0.63 \pm 0.10 \mathrm{mg} / \mathrm{dL}$. The best results were recorded for groups which group treated with $30 \%$ cooked potato $(0.67 \pm 0.05 \mathrm{mg} / \mathrm{dL})$ followed by $10 \%$ raw potato $(0.83 \pm 0.14 \mathrm{mg} / \mathrm{dL})$. These results are confirmed with Abd-Elmeged and Alzahrani (2018) improved that diabetic rats fed on taro, carrot, sugar beet and sweet potato showed significant decrease of urea and creatinine compared to diabetic groups.

Purple sweet potato tuber extract lowers mallondialdehyde and improves plasma glucose through several mechanisms, and that the extract was safe for the liver and kidney functions (Mahaditaet al, 2016). 
Table (8): Effect of sweet potato powder on kidney functions in serum of diabetic rats

\begin{tabular}{|c|c|c|}
\hline Groups & Urea(mg/dL) & Creatinine(mg/dL) \\
\hline Negative control & $42.40 \pm 2.42^{\mathrm{ab}}$ & $0.63 \pm 0.10^{\mathrm{b}}$ \\
\hline Positive control & $46.83 \pm 5.34^{\mathrm{a}}$ & $0.92 \pm 0.10^{\mathrm{a}}$ \\
\hline $\mathbf{1 0 \%}$ raw potato & $41.60 \pm 5.71^{\mathrm{ab}}$ & $0.83 \pm 0.14^{\mathrm{a}}$ \\
\hline $\mathbf{3 0 \%}$ cooked potato & $38.83 \pm 5.56^{\mathrm{b}}$ & $0.67 \pm 0.05^{\mathrm{b}}$ \\
\hline
\end{tabular}

Means in the same column with various letters are significantly varied at $(\mathrm{p}<0.05)$.

\section{Histopathological experimental to pancreas in diabetic rats}

Pancreas of rat from control negative group revealed that no histopathological changes (Photo.1). Meanwhile, pancreas of rat in group-2 (control positive rats) showed a vaculation of cells of islets of Langerhans's and congestion of pancreatic blood vessels (Photo.2). Pancreas of rat in Group 3 resaved with (10\% raw potato) showed no histopathological changes (Photo.3) but, pancreas of rat in-group 4 treated with (30\% cooked potato) showed a congestion of pancreatic blood vessels (Photo.4). These results are agreement withAl-Qudah et al. (2016) who found that in diabetic control rats, abnormalities in the pancreas were found. The congestion of RBCs in blood vessels, in addition, thickening of the septa, was clearly shown. Furthermore, the islets of Langerhans have been prominently varied and a slight differences in its cells was noticed as appear (Al-Qudah et al., 2016).

Microscopic histopathological of pancreatic tissues observed a marked lower in the islets of Langerhans size accompanied by a significantly reduced in the number of $\beta$-cells, insulin-secreting cells, in the diabetic group. These abnormalities were healed after therapy of diabetic rats with BV, which could have the ability to regenerate beta cells of islets of Langerhans. (Elkotby et al., 2018).

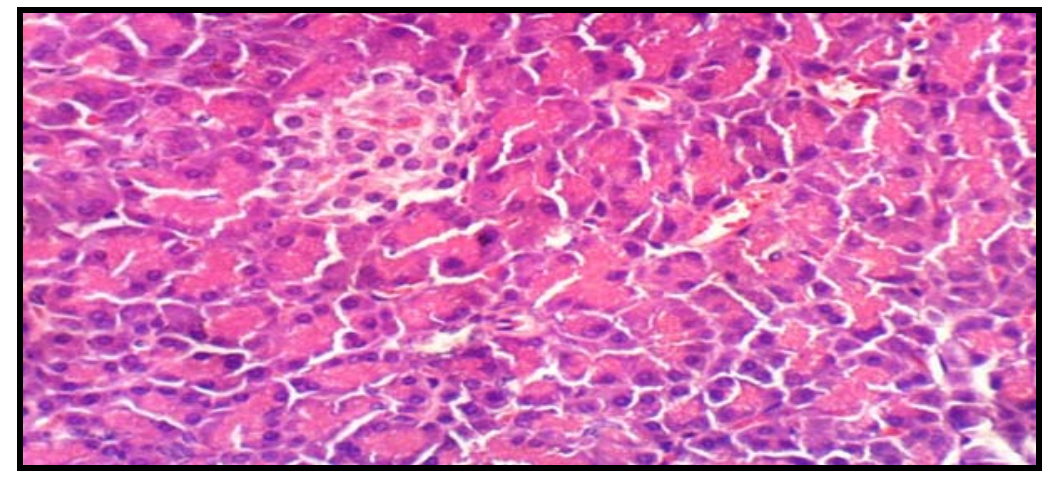

Photo (1): Pancreas of rat from group 1 (control negative) showing no histopathological changes (H \& E X 400) 


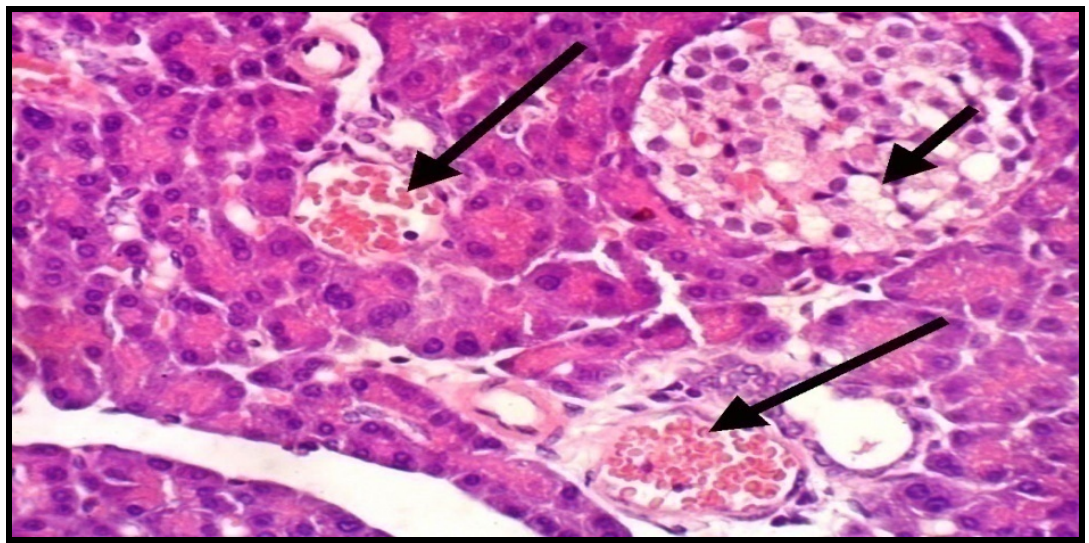

Photo (2): Pancreas of rat from group 2 (control positive) showing vaculation of cells of islets of Langerhans's and congestion of pancreatic blood vessels (H \& E X 400).

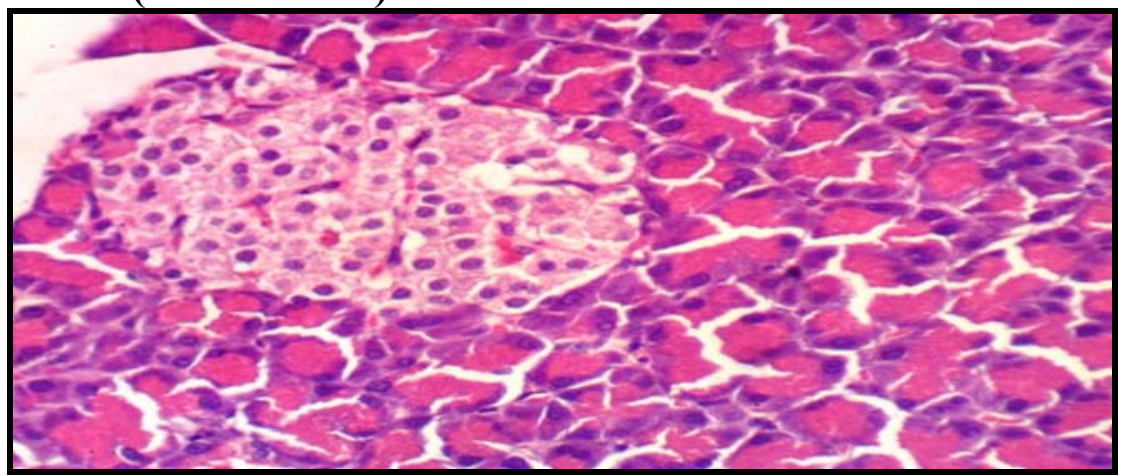

Photo (3): Pancreas of rat from group $3(10 \%$ row potato) showing no histopathological changes (H \& E X 400).

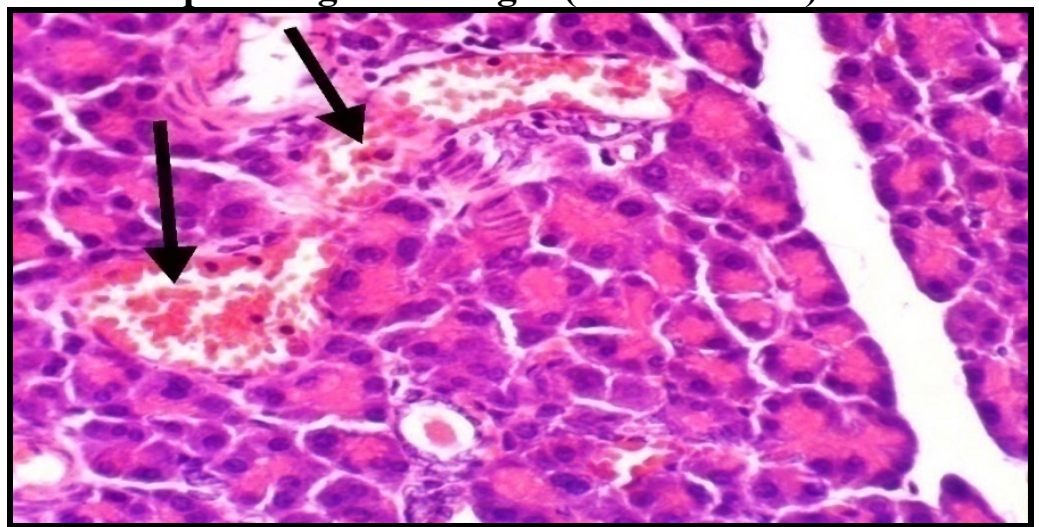

Photo (4): Pancreas of rat from group $4(30 \%$ cooked potato) showing congestion of pancreatic blood vessels (H \& E X 400). 


\section{CONCLUSION}

From the obvious results, it could be concluded that the potato raw and cooked had contained high amounts of carbohydrates, protein, fiber and some minerals. The biological experimental was fed on $10 \%$ raw potato and $30 \%$ cooked potato and the results observed that the glucose level, lipid profile, liver and kidney functions were improved in diabetics' rats' group. Therefore, it could be recommended that the biscuits prepared from 10 and 30\% from raw and cooked sweet potatoes had contained a good source of nutrition value and improved lipid profile and glucose in the blood.

\section{REFERENCES}

Abd- Elmeged, M. S. L. and Alzahrani, A. M. N. (2018): The therapeutic effect of some tuber plants that found in the Al-Baha area on biochemical changes in hyperglycemic rats Journal of American Science, 14(6):84-95.

ADA, American Diabetes Association (2017): Standards of medical care in diabetes. Diabetes Care 40: 11-24.

Akram, A.N.,M.,Daniyal,M. and Ahmad,S.(2018):Evaluation of antidiabetic activity ofIpomoeabatatasL.extract in alloxan -induced diabetic rats.International Journal of Immunopathology, 32:1-6.

Alam, M. K., Rana, Z. H. and Islam, S. N. (2016): Comparison of the proximate composition, total carotenoids and total polyphenol c content of nine orange-fleshed sweet potato varieties grown in Bangladesh. Foods, 5:64.

Allain, C. C., Poon, C. S. G., Chan, Richmond, W. and Fu, P. C. (1974): Enzymatic determination of serum cholesterol. Clin., Chem., 20:470-475.

Al-Qudah, M. M., Haddad, M. A., El-Qudah, J. M. (2016): The effects of aqueous ginger extract on pancrease histology and on blood glucose in normal and alloxan monohydrate in duced diabetic rats. Biomedical Research, 27(2):350-356.

AOAC (2012). Official Method of Analysis. $19^{\text {th }}$ Edn., Association of Official Analytical Chemists, Washington DC., USA.

Carleton, H. (1979): Histological techniques. $4^{\text {th }} \mathrm{cdn}$., oxford university press, London, New york.

Duncan, D. B. (1955): Multiple range test and multible F tests. Biometric, 11(1):1-42.

Elkotby, D., Hassan, A. K., Emad, R. and Bahgat, I. (2018):Histological changes in islets of Langerhans of pancrease in alloxan induced diabetic rats following Egyptian honey bee venom treatments. International journal of pure and applied Zoology, 6(1):1-6. 
Eusebio, P. S., Coloso, R. M. and Mamauag, R. E. (2004): Apparent digestibility of selected ingredients in diets for juvenile grouper, Epinepheluscoioides (Hamilton). Aquacult. Res., 35: 1261-1269.

Fogelman, Y., Kitai, E., Blumberg, G., Golan-Cohen, A., Rapoport, M. and Carmeli, E. (2017):Vitamin B12 screening in metformin- treated diabetics in primary care: were elderly patients less likely to be tested?. Aging. Clin. Exp. Res. 29: 135-139.

Friedwald, W. T., Levy, R. L. and Fredrickson, D. S. (1972): A system for phenotyping hyper lipoproteinemia. (PDF). Circulation. 31:321-327.

Ganiyat, O. O., Folake, O. H., Michael, A. I. and Keith, T. (2016):Quality attributes of sweet potato flour as influenced by variety, pretreatment and drying method. Food science and Nutrition, 4(4):623-635.

Ghosh, D. and Konishi, T. (2007):Anthocyanins and anthocyanin-rich extracts: role in diabetes and eye function. Asia Pac. J. Clin. Nutr 16(2): 820.

He, W., Zeng, M., Chen, J., Jiao, Y., Niu, F., Tao, G., Zhang, S., Qin, F. and He, Z. (2015): Identification and quantitation ofanthocyanins in purple-fleshed sweet potatoes cultivated in China by UPLC-PDA and UPLCQTOF-MS/MS. J. Agric. Food Chem., 64: 171-177.

Hegazi, R., EL-Gamal, M., Abdel-Hady, N. and Hamdy, O. (2015): Epidemiology of and risk factors for type 2 diabetes in Egypt. Annals of global health, 81(6):814-820.

Hossen, M. S., Gan, S. H. and Khalil, M. I. (2017):Melittin, a potential natural toxin of crude bee venom: probable future arsenal in the treatment of diabetes mellitus. J. Chem. 1-7.

Jawi, I. M. and Budiasa, K. (2011). Ekstrak air umbiubijalarungumenurunkan total kolesterolsertameningkatkan total antioksidanpadadarahkelinci. J VeterinerJurnalKedokteranHewan Indonesia 12 (2): 120-125.

Jawi, I. M., Arijana, I. G., Subawa, A. A. and Wirasuta, I. M. (2016): The pharmacological mechanisms of anthocyanin in aqueous extract of purple sweet potato as anti-hyperglycemic Herbal Remedy. Global Journal of Medical Research:Pharma Drug Discovery, Toxicology and Medicine, 16(2):22-46.

Kaplan, A. (1984): Urea. Clin Chem., 1257- 1260 and 437 and 418.

Latha, S., Rajaram, K. and Suresh, K. P. (2013):Hepatoprotective and antidiabetic effect of methanol extract of Carallumafimbriata in streptatozocin induced diabetic albino rats. Int. J. Pharm. Pharmaceut. Sci., 6: 665-668

Mahadita, W. G., Jawi, M. and Suastika, K. (2016):Purple sweet potato tuber extract lowers mallondialdehyde and improves glycemic control in subjects with type 2diabetes mellitus. Global Advanced Research Journals, 5(7):208-213. 
Murray, R. (1984): Alanine aminotransferase. J. Clin. Chem., 1088- 1090. Nizamutdinova, I. T., Jin, Y. C., Chung, J. I., Shin, S. C., Lee, S. J., Seo, H. G., Lee, J. H., Chang, K. C. and Kim, H. J. (2009): The anti- diabetic effect of anthocyanins in streptozotocin-induced diabetic rats through glucose transporter 4 regulation and prevention of insulin resistance and pancreatic apoptosis. MolNutr Food Res. 53(11): 1419-29.

Omodariniro, O. D. and Omodamiro, R. M. (2018):Evaluation of hypoglycemic and hypolipidemic potentials of sweet potato on awisttar Albino rat. American Journal of Advanced drug delivery, http//: www. imedpub. com/ advanced -drug -delivery /.

Onabanjo, O. O. and Ighere, D. A. (2014): Nutritional, functional and sensory properties of biscuits produced from wheate sweet potato composite. Journal Food Technology Research, 1(2):111-121.

Park, S. Y., Lee, S. Y., Yang, J. W., Lee, J. S., Oh, S. D., Oh, S., Lee, S. M., Lim, M. H., Park, S. K. and Jang, J. S. (2016): Comparative analysis of phytochemicals and polar metabolites from colored sweet potato (Ipomoea batatas L.) tubers. Food SciBiotechnol, 25: 283-291.

Pell, J.D., Gee, J.M., Wortley, G.M. and Johnson, I.T. (1992). Both dietary corn oil and guar gum stimulate intestinal crypt cell proliferation in rats, by independent but potentially synergistic mechanisms. J. Nutr., 122, 2447-2456.

Rafiu, A. A. and Luka, C. D. (2018): Effect of aqueous extract of Ipomoea batatasleaf on blood glucose, kidney functions and hematological parameters of streptozotocin -induced diabetic rats. Journal of research of diabetes and metabolism, 4(1):4-9.

Rodrigues, N. R., Junior, B. J. and Barbosa, M. I. (2016):Determination of physico-chemical composition, nutritional facts and technological quality of organic orange and purple fleshed sweet potatoes and its flours. International Food Research Journal, 23(5):2071-2078.

Samiha, A. A. (2015): Chemical, physical and sensory properties of sweet potato cake. Egypt. J. Agric. Res., 93(1):101-115.

Sandu, M. M., Protasiewicz, D. C., Firănescu, A. G., Lăcătușu, E. C., Bîcu, M. L. and Moța, M. (2016): Data regarding the prevalence and incidence of diabetes mellitus and prediabetes. Romanian J Diabetes Nut. Metabolic. Dis. 23: 95-103.

Shaohualiu and Yunongli (2016): Effect of nano sweet potato residue cellulose on blood glucose level of athletes. Carpathian Journal of food science and technology, 8(3):13-21

Srijita, D. (2015): Sweet potatos for diabetes mellitus:Asystematic review. Pharmacophore(An international Research Journal, 6(1):60-72.

Strugała, P., Dzydzan, O., Brodyak, I., Kucharska, AZ., Kuropka, P., Liuta, M., Kaleta-Kuratewicz, K., Przewodowska, A., Michałowska, D., 
Gabrielska J. and Sybirna, N.(2019). Antidiabetic and Antioxidative Potential of the Blue Congo Variety of Purple Potato Extract in Streptozotocin-Induced Diabetic Rats, Molecules 2019, 24, 3126. 1-22.

Sudha, M. L., Vetrimani, R. and Leelavathi, K. (2007): Influence of fiber. from different cereals on the rheological characteristics of wheat..dough and on biscuits quality. J. Food. Chem., 100:1365 - 1370

Teow, C. C. (2007): Antioxidant activity and bioactive compounds ofsweet potato, Master of Science Food Science (thesis). North Carolina State University, Raleigh, 5(2):90-98.

Trindad, P. T., Rosario, S. S., Aida, C. M., Melissa, S. B., Marco, P. D. and Theressa, F. A. (2013): Sweet potato and cassava can modify cholesterol profile in humans with moderately raised serum cholesterol levels. Food and Nutrition sciences, 4:491- 495.

Trinder, P. and Ann (1969): Serum triglycerides. J. Biol. Chem., 6:24-33.

Trinder, P. (1969): Determination of glucose in blood using glucose. oxidase with an alternative oxygen acceptor. Ann. Clin. Biochem.,. 6:24-25.

Tuomi, T., Santoro, N., Caprio, S.,Cai, M., Weng, J. and Groop, L. (2014): The many faces of diabetes: a disease with increasing heterogeneity. The lancet, 383(9922):1084-1094.

Udayakumar, R., Kasthurirengan, S., Ma riashibu, T. S., Rajesh, M. and Rajesh, M. and Anbazhagan, V. R. (2009):Hypoglycaemic and hypolipidaemiceffects of Withaniasomnifera root and leaf extracts on alloxaninduced diabetic rats. Int. J. Mol. Sci., 10: 2367-2382.

Wang, S., Nie, S. and Zhu, F. (2016): Chemical constituents and health effects of sweet potato. Food Research International, 89:90-116.

Wenger, C. and Kaplan, A. (1984): Alkaline phosphatase. Clin Chem., 10941098.

World Health Organization (WHO) (2018): diabetes. World Health Organization: 8. https: www. who. int news- room fact- sheets details diabetes. Yaday, J.P., Saini, S., Kalia, A.N.andDangi,A.S.(2008): Hypoglycemic and hypolipidemic activity of ethanolic extract of Salvadoraoleoides in normal and alloxan induced diabetic rats. Indian. J. Pharmacol.,40:23-7. 


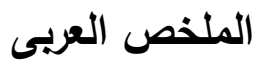

\section{تأثير استخدام مسحوق البطاطا على الفئران المصابة بأرتفاع السكر فى الام}

يهدف البحث لمعرفة تأثير العلاج بمسحوق البطاطا الحلوة النيئة والمطبوخة على الفئران

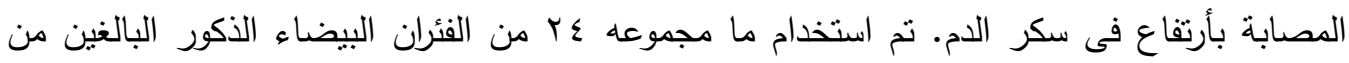

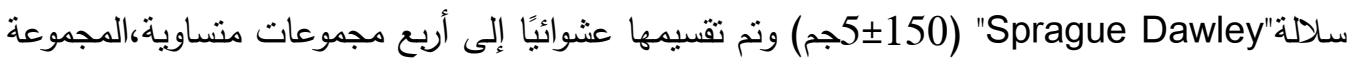

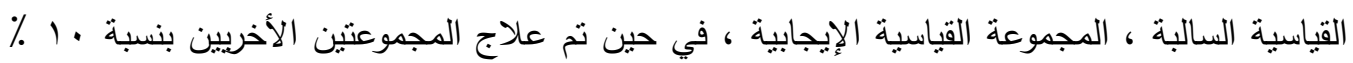
من البطاطس الخام و •r٪ البطاطس المطبوخة حسب التقييم الحسي للبسكويت. استمرت التجربة للددة

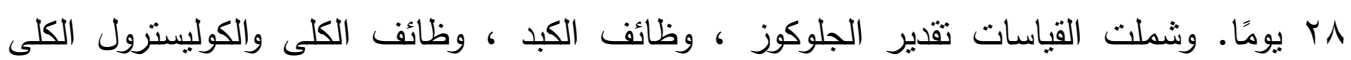
والجليسريدات الثلاثية والليبوبروتين منخفض ومرتفع الكثافة وتحليل الأنسجة البنكرياسية.

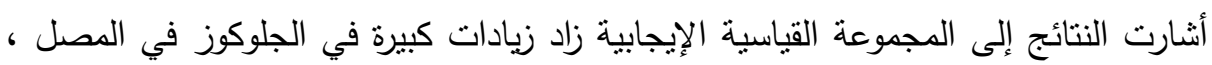
بالإضافة إلى زيادة كبيرة في وظائف الكبد والكلى ، والكوليسترول الكلى والجليسريدات الثلاثية

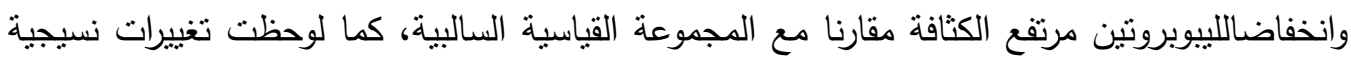
غير طبيعية فى البنكرياس بسبب أرتفاع سكر الدم. البطاطا الحلوة الخام والمطبوخة كان لها نأثيرات

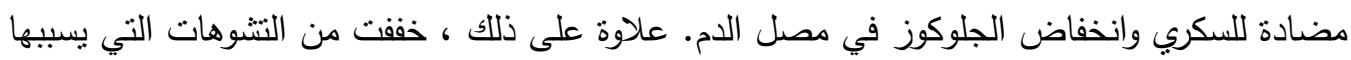

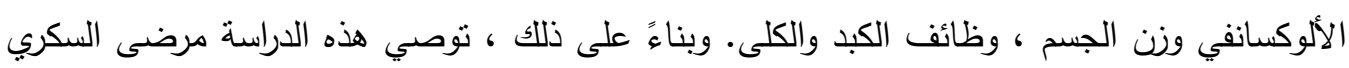

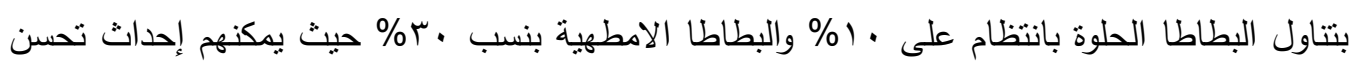
في زيادة نسبة السكر في الدم. مفتاح الكلمات: سكر الدم- الألوكسان - البطاطا الحلوة- شكل اللبيدات 